\title{
Author Correction: Regulation of local GTP availability controls RAC1 activity and cell invasion
}

Anna Bianchi-Smiraglia (D, David W. Wolff(D, Daniel J. Marston, Zhiyong Deng, Zhannan Han, Sudha Moparthy, Rebecca M. Wombacher, Ashley L. Mussell, Shichen Shen, Jialin Chen, Dong-Hyun Yun, Anderson O'Brien Cox, Cristina M. Furdui (D), Edward Hurley, Maria Laura Feltri (D), Jun Qu, Thomas Hollis (D), Jules Berlin Nde Kengne, Bernard Fongang, Rui J. Sousa (D), Mikhail E. Kandel (1D), Eugene S. Kandel, Klaus M. Hahn (1D \&

Mikhail A. Nikiforov (1D

Correction to: Nature Communications https://doi.org/10.1038/s41467-021-26324-6, published online 19 October 2021.

This Article contained an error in Fig. 1. In Fig 1b, the GEVAL30 and GEVALNull labels for the images of both MDA-MB-231 and SK-Mel-103 cells were inadvertently switched.

Published online: 05 November 2021

(c) Open Access This article is licensed under a Creative Commons Attribution 4.0 International License, which permits use, sharing, adaptation, distribution and reproduction in any medium or format, as long as you give appropriate credit to the original author(s) and the source, provide a link to the Creative Commons license, and indicate if changes were made. The images or other third party material in this article are included in the article's Creative Commons license, unless indicated otherwise in a credit line to the material. If material is not included in the article's Creative Commons license and your intended use is not permitted by statutory regulation or exceeds the permitted use, you will need to obtain permission directly from the copyright holder. To view a copy of this license, visit http://creativecommons.org/licenses/by/4.0/.

(C) The Author(s) 2021 